\title{
Can a PCR assay of aphids caught in-crop on yellow sticky traps inform field level barley yellow dwarf virus (BYDV) risk assessment?
}

by Bates, L.J., Pope, T.W. and Holland, J.M.

Copyright, publisher and additional information: this is the author accepted manuscript. The final published version (version of record) is available online via Wiley. This article may be used for non-commercial purposes in accordance with Wiley Terms and Conditions for Self-Archiving.

Please refer to any applicable terms of use of the publisher.

DOI: https://doi.org/10.1111/aab.12601 
1 Can a PCR assay of aphids caught in-crop on yellow sticky traps inform field

2 level barley yellow dwarf virus (BYDV) risk assessment?

\section{Abstract}

5 Infection with barley yellow dwarf virus (BYDV), caused by strains of virus belonging to the

6 family Luteovirideae including BYDV-PAV, can result in significant yield losses in autumn sown

7 cereals following transmission by aphid vectors such as Rhopalosiphum padi (Homoptera:

8 Aphididae) and Sitobion avenae (Homoptera: Aphididae). Spatial and temporal variance in the

9 infectivity of alate populations influences risk to crops from the disease, which is greatest on

10 infection at early crop growth stages. A decision support system (DSS) to guide optimised 11 integration of crop protection strategies through risk assessment would help avoid unnecessary application of synthetic insecticides. This study contributes to the development of a DSS by exploring the viability and relevance of a methodology to detect virus levels in individual aphids trapped in-crop using yellow sticky traps. Using a reverse transcription polymerase chain reaction (RT-PCR) assay, the detectability of virus from a BYDV-PAVpositive control colony was found not to be reduced by the process of trapping, extraction and cold storage, but did drop significantly after between three and seven days of exposure on trap. This method has potential to contribute to localised risk assessment and guide optimisation of crop protection strategies.

Keywords: BYDV, Sitobian avenae, Rhopalosiphum padi, infectivity, winter cereals, crop protection, integrated pest management 
Viral diseases vectored by aphids (Aphididae) cause major crop losses worldwide ( $\mathrm{Ng}$ and Perry, 2004; Hull, 2009; van Emden and Harrington, 2017. Barley yellow dwarf virus (BYDV) is one of the most widespread and economically damaging of these (D'Arcy 1995; Bicknell et al., 2000; Jarošová et al., 2016). Infection by the Luteovirus and Polerovirus genera of the family Luteovirideae typically result in qualitative and quantitative reduction in yield through chlorosis, root and shoot stunting and reduced stress tolerance (Herbert et al., 1999; Riedell et al., 2003), symptoms collectively described as barley yellow dwarf disease (BYDD). Three distinct strains are responsible for causing crop losses in UK cereals, all of which are phloemrestricted and transmitted in a circulative non-propagative manner by aphid vectors (Gray and Gildow, 2003). BYDV-PAV is vectored by Rhopalosiphum padi (Linnaeus) and Sitobian avenae (Fabricius) (Rochow, 1970). Crops are most vulnerable to infection before Zadoks growth stage 31 (Doodson and Saunders, 1970; Zadoks et al., 1974).

BYDV epidemiology is governed by a complex ecology of biotic and abiotic interactions involving virus, vector, host and climate (Miles, 1989; Irwin and Thresh, 1990; Walls et al., 2019). Incidence and impact of the disease consequently varies between years, areas and crops at a localised scale (Plumb, 1974; Watt, 1983; McGrath and Bale, 1989; Holland et al., 2019). A major factor in disease incidence is the number of viruliferous alate aphids alighting on young crop plants (Lowles et al., 1997; Bicknell et al., 2000; Fabre et al., 2006). Conditions including temperature that govern survival, colonisation through anholocyclic parthenogenesis and in-crop movement dictates subsequent disease development and secondary spread (Kendall et al., 1992; Fabre et al., 2006; Powell and Bale, 2006). With no established functional relationship between aphid infestation and virus-related damage, there have historically been no reliable economic thresholds (Oakley and Walters, 1994; Herbert et al., 1999), making prophylactic chemical control the primary course of crop protection in conventional UK arable systems (Dewar and Denholm, 2017; Walls et al., 2019). Reduced availability and efficacy of synthetic pesticides due to growing awareness of environmental risks (Pimentel and Lehman, 
51 1993; Pisa et al., 2014; Handford et al., 2015) combined with increasingly widespread 52 insecticide resistance in aphid populations (Dewar and Foster, 2017) increases the mandate for alternative approaches to BYDV virus vector management.

Sustainable protection of crops from BYDV requires confidently informed and implemented decision support systems (DSSs) to enable land managers to appropriately integrate pest control strategies (Stern et al., 1959; Knight, 1997). These may include cultural control (Tatchell et al., 1988), conservation biological control (Woodcock et al., 2016), varietal genetic tolerance or resistance to viruses or vectors (Jarošová et al., 2016; Aradottir et al., 2017) and pesticide application (Dewar and Denholm, 2017). Operating within an economic framework of cost benefit analysis (Shtienberg, 2013) and a regulatory framework of environmental legislation (Handford et al., 2015), uptake of DSSs relies on the perception of minimal risk of false negative advice (Gent et al., 2011; Gent et al., 2013). Reliable forecasting of future outbreaks to inform crop protection decisions benefits from the aggregation of multiple factors into modelling and the combining of multiple forecasts (Bates and Granger, 1969; Lankin-Vega et al., 2008).

Long term monitoring through national and continental suction trap networks has contributed migration (Tatchell et al., 1988; Lowles et al., 1997). For this reason, analysis of specimens from the most commonly operated $12.2 \mathrm{~m}$ high suction trap model cannot accurately represent in-crop infectivity levels (Burgess et al., 1999), undermining the relevance of a DSS based on this data alone (Gent et al., 2013; Ramsden et al., 2017). In-crop monitoring can help to more accurately guide management decisions at a localised level. Yellow sticky traps have been found to offer a low cost, low maintenance means of 
quantifying relative abundance of aphids (Harrington et al., 2007) including $S$. avenae and $R$. padi in autumn cereal crops (Holland et al., 2019). Sample extraction from sticky traps using alkane solvents has been found in other entomological studies to preserve the integrity of samples for identification (Davidson et al., 2015) and of viral RNA for assay (Boonham et al., 2002; Congdon et al., 2019). Singh et al., 1997, found detectability of viral RNA by RT-PCR to be retained in individual aphids stored for up to seven years in $70 \%$ ethanol.

Assays to facilitate the rapid and reliable discrimination and quantification of BYDV strains including -PAV have been developed using both reverse transcription loop-mediated isothermal amplification (RT-LAMP) (Zhao et al., 2010) and real-time reverse-transcription polymerase chain reaction (RT-PCR) (Canning et al., 1996; Fabre et al., 2003; Malmstrom and Shu, 2004; Kundu et al., 2009) techniques. RT-PCR assay through allelic discrimination using Taqman probes was found by Fabre et al., (2003) to be $10^{3}$ times more sensitive than its ELISA predecessor in the detection of BYDV-PAV. This study establishes the viability of applying a RT-PCR assay quantifying the presence of BYDV-PAV through allelic discrimination using Taqman probes (Williamson, unpublished, 2018) to aphid samples acquired through yellow sticky trapping followed by extraction using a commercial solvent and cold storage. The amount of time for which positive samples remain detectable by the assay once exposed on trap is established through a time-series field experiment.

\section{Materials and methods}

\subsection{Control colony}

To establish the viability of using in crop yellow sticky traps in combination with RT-PCR assay for detection of BYDV-PAV in aphid vectors, $R$. padi adults from a BYDV-PAV-positive colony from Rothamsted Research (Harpenden, Hertfordshire, UK) were placed onto yellow sticky traps ('Wetstick', Oecos Ltd, Hertfordshire, UK) for between 0 and 14 days prior to RT-PCR 
assay. Aphids taken directly from the colony for use in the RT-PCR assay were used as a control.

\subsection{Trap type and preparation}

Rhopalosiphum padi from the BYDV-PAV-positive colony were placed live onto $1520 \mathrm{~cm} \mathrm{x}$ $10 \mathrm{~cm}$ yellow sticky traps. Fifty aphids were placed live on each trap in a $3 \mathrm{~mm}$ grid pattern to ensure they could be identified from any ingressing aphids becoming stuck to the traps.

\subsection{Field site}

The field site used in this study was located in Wiltshire $\left(51^{\circ} 18^{\prime} 08^{\prime \prime} \mathrm{N}, 2^{\circ} 03^{\prime} 16^{\prime \prime} \mathrm{W}\right.$, elevation $59 \mathrm{~m})$. Yellow sticky traps were erected parallel to the soil surface at a height of $25 \mathrm{~cm}$ using rigid plastic canes inserted into holes drilled into the centre of either end of the traps and driven $10 \mathrm{~cm}$ into the ground. The traps were positioned $5 \mathrm{~m}$ from the hedged eastern edge of a direct drilled winter wheat crop at GS13 (Zadoks et al., 1974). The experiment was completed between December 3rd and December 17th 2018. Traps were removed from the field at 24hour intervals but constraints of assay capacity restricted analysis to specimens removed after $0,1,3,7,10$ and 14 days. Maximum and minimum air temperatures for the preceding 24 hours were recorded at each removal point using a digital thermometer (Electronic Temperature Instruments Ltd, West Sussex, UK).

\subsection{Specimen extraction and storage}

Aphids were extracted from traps using a commercial alkane solvent formulation of $60 \%$ aliphatic hydrocarbon and 40\% glycol ether (Mykal 'De-Solv-It Sticky Stuff Remover' UK Ltd, Cheshire, UK). Once removed from the trap, specimens were immediately placed in $5 \mathrm{ml}$ clear plastic vials of $95 \%$ ethanol in batches of 15 and stored at $-5^{\circ} \mathrm{C}$. 


\subsection{RT-PCR assay}

130 A real time RT-PCR Taqman assay for detection of BYDV-PAV in cereal aphids (Williamson, unpublished, 2018) was performed on aphid samples at Rothamsted Research between

132 February $4^{\text {th }}$ and February $8^{\text {th }} 2019$ to detect levels of the virus present in individual specimens. Aphids were homogenised in a sucrose/salt buffer to lyse cells and subjected to reverse transcription with revertaid RT enzyme (ThermoFisher UK) to convert any BYDV viral RNA present into cDNA. BYDV-PAV DNA was then identified by Taqman PCR using BYDV-PAV specific primer and probe sequences. The assay was run through 30 cycles using an Applied Biosystems 7900HT real-time PCR cycler and scored according to an increase in marker dye (VIC) fluorescence when BYDV-PAV DNA was amplified in the reaction above a baseline at which little or no change in flourescence was detected. A threshold was applied to determine positive BYDV-PAV infection relative to the score for negative control samples. Control samples for negative virus infection were taken from a colony of $R$. padi that was not exposed to BYDV-PAV and consistently fell below threshold levels of detectable flourescence. Controls for positive virus infection were duplications of samples taken from $R$. padi that were from a colony exposed to BYDV-PAV and individually determined to score above the threshold, as infectivity within an infected colony varies between individuals. Control aphids (+/- virus infection) and a no-template control of sterilized $\mathrm{H}_{2} \mathrm{O}$ were included on all assay plates.

\subsection{Statistical analysis}

A total of 126 samples from time points $0,3,7,10$ and 14 days were analysed. Twenty-eight positive controls (aphids taken directly from the same BYDV-PAV infected colony) were assayed using the same technique. Detected virus load of individual aphids compared to negative control samples at each time point were plotted in $\mathrm{R}$ version 3.5.3 ( $\mathrm{R}$ Core Team, 
2019). Significance of variation in the dependent variable of BYDV-PAV virus load indicated by a detected increase of the flourescence reporter signal during amplification from that of aphids taken from the same infected colony but not exposed on trap were analysed using a series of $t$-tests and overall analysis of variance (ANOVA) according to the independent variable factor of 'days on trap'.

\section{Results}

The detectability of BYDV-PAV by PCR assay did not vary significantly from the control (-1 days) after either 0 days $\left(F_{1,59}=1.94, P=0.06\right)$ or 3 days $\left(F_{1,36}=0.08 ; P=0.8\right)$ on trap (Figure 1.). There was a significant reduction, however, in detectability at 7 days $\left(F_{1,56}=9.46 ; P\right.$ $=0.003), 10$ days $\left(F_{1,42}=11.55 ; P=0.002\right)$ and 14 days $\left(F_{1,63}=15.94 ; P=<0.001\right)$ (Figure 1.). Although the mean detectability had dropped by 7 days, it remained possible to detect virus carrying aphids. Half of the 82 individuals sampled between 7 and 14 days were still determined as BYDV-PAV-positive.

Temperatures recorded during this study were a maximum of $12.0^{\circ} \mathrm{C}$, a minimum of $-3.0^{\circ} \mathrm{C}$, a mean maximum of $9.3^{\circ} \mathrm{C}$ and a mean minimum of $4.0^{\circ} \mathrm{C}$. The temperatures recorded in this study were, therefore similar to the 1991-2010 averages for Southern England in November (Table 1).

\section{Discussion}

Results from this study indicate that the in-crop use of yellow sticky traps and subsequent use of a RT-PCR assay is a viable approach with which to assess the BYDV-PAV infectivity levels of in-crop aphid populations. The results show that the process of trapping, extraction and storage according to the protocol followed does not reduce the detectability of the virus by RTPCR assay $\left(F_{1,59}=1.94 ; P=0.06\right)$. The length of time that aphids remain on trap in the field 
179 for does however affect detectability $\left(F_{1,151}=15.21 ; P=<0.001\right)$ with a significant drop 180 occurring between three and seven days $\left(F_{1,38}=5.04 ; P=0.04\right)$.

181 To be utilised effectively, an optimum timeframe for trap exposure in the field is required to 182 maximise the accuracy of virus detection whilst minimising the amount of work required by operatives in the field and cost of materials. Further study to find a more precise timeframe would be needed before the method could be confidently applied, and it would be reasonable to concentrate this on the three to seven-day window.

It is not currently known at what viral titre an individual aphid vector poses a tangible risk to crops through transmission of BYDV-PAV. Further study to determine this parameter would establish confidence in the method and help inform economic injury level thresholds for control. This could prove a valuable addition to the use of sticky traps in determination of spray thresholds (see Holland et al., 2019).

Similarly, the technique used here could be used to investigate factors affecting risk variability within fields. It is established that migrating alate aphids are more likely to land at field edges due to visual cues including long-wavelength light reflected by the plant-soil boundary (Schroder et al., 2015) and may also be influenced by local wind currents around boundary features (Holland et al., 2019). If, when repeated, higher numbers of virus carrying aphids were consistently found nearer to headlands, the risk of headland crops contracting BYDV could warrant selective spraying, landscape manipulation to facilitate conservation biological control or the sowing of resistant or tolerant crop varieties at field margins.

Establishing the confidence required for uptake and application as part of a DSS would require further investigation into how air temperature during exposure on-trap affects detectability of the virus in aphid specimens. Air temperature has previously been shown to be important in determining the detectability of Tomato spotted wilt virus in sticky-trapped thrips (Okazaki et al., 2011). Atmospheric temperatures will vary between seasons and sites according to region, aspect, elevation and exposure. This is highlighted by extensive recognition of 
temperature as a factor in the interannual variability of aphid population dynamics contributing to BYDV epidemiology (Kendall et al., 1992; Fabre et al., 2006; Powell and Bale, 2006). If air temperature during on-trap exposure was shown to be a factor in the reliability of the method, a calculation of optimum cumulative day degrees of trap exposure may be more appropriate than purely time-based guidance.

BYDV-PAV is just one of three causal viruses responsible for crop losses through BYDD in UK crops, and the prevalence of these varies annually (Harrington et al., 1999). Although this study focusses on the distinct BYDV-PAV strain, studies such as Malmstrom and Shu (2004), Kundu et al. (2009) and Zhao et al. (2010) have established simultaneous discrimination and quantification of several viral strains is possible. The comparison of compatibility of this trapping and processing method with different assays, including those using the simpler and quicker RT-LAMP technique (Mori and Notomi, 2009; Congden et al., 2019b.) could broaden the application of the method to BYDD risk from other viral strains including BYDV-MAV and CYDV-RPV. Similarly, exploration of the compatibility of the assay with other in-crop trapping techniques such as water-pan traps, which require higher levels of maintenance than sticky traps but provide specimens in better condition for identification and processing (Harrington et al., 2007) may improve the method's efficiency.

Once optimised, this localised and rapid assay of aphids trapped in-crop could inform BYDV risk assessment at field level by giving a measure of infectivity of ingressing aphids. Feeding this data into an aggregated model would help to reliably forecast the economic risk posed to an individual crop following primary infection and secondary spread of the disease taking into account growth stage at vector ingression and seasonal temperatures. Understanding of the complex nature of BYDV epidemiology, including the influence of surrounding land use, could be improved using this tool and contribute to the establishment of economic thresholds for insecticide application. 
232 RT-PCR assays were completed at Rothamsted Research with funding from AHDB Cereals 233 and Oilseeds project no. 21120077 'Field monitoring of BYDV risk in winter cereals'. Thanks 234 to R. Johnson on whose farm the experiment was located. 
A'Brook, J., \& Dewar, A. M. (1980). Barley yellow dwarf virus infectivity of alate aphid vectors in West Wales. Annals of Applied Biology, 96(1), 51-58.

Aradottir, G. I., Martin, J. L., Clark, S. J., Pickett, J. A., \& Smart, L. E. (2017). Searching for wheat resistance to aphids and wheat bulb fly in the historical Watkins and Gediflux wheat collections. Annals of Applied Biology, 170(2), 179-188.

Bates, J. M., \& Granger, C. W. (1969). The combination of forecasts. Journal of the Operational Research Society, 20(4), 451-468.

Bell, J. R., Alderson, L., Izera, D., Kruger, T., Parker, S., Pickup, J., et al. (2015). Long-term phenological trends, species accumulation rates, aphid traits and climate: Five decades of change in migrating aphids. Journal of Animal Ecology, 84(1), 21-34.

Bicknell, K., Greer, G., \& Teulon, D. (2000). The value of forecasting BYDV in autumn sown cereals. Paper presented at the Proceedings of the New Zealand Plant Protection Conference, pp. 87-92.

Boonham, N., Smith, P., Walsh, K., Tame, J., Morris, J., Spence, N., et al. (2002). The detection of tomato spotted wilt virus (TSWV) in individual thrips using real time fluorescent RT-PCR (TaqMan). Journal of Virological Methods, 101(1-2), 37-48.

Burgess, A. J., Harrington, R., \& Plumb, R. T. (1999). Barley and cereal yellow dwarf virus epidemiology and control strategies. The Luteoviridae.HG Smith and H.Barker, Eds. CABI, Wallingford, England, pp. 211-279.

Canning, E., Penrose, M. J., Barker, I., \& Coates, D. (1996). Improved detection of barley yellow dwarf virus in single aphids using RT-PCR. Journal of Virological Methods, 56(2), 191-197.

Congdon, B. S., Kehoe, M. A., Filardo, F. F., \& Coutts, B. A. (2019). In-field capable loopmediated isothermal amplification detection of turnip yellows virus in plants and its principal aphid vector myzus persicae. Journal of Virological Methods, 265, 15-21. 
D'Arcy, C. J. (1995). Symptomatology and host range of barley yellow dwarf. Barley Yellow Dwarf, 40, 9-28.

Davidson, M. M., Nielsen, M., Butler, R. C., Vellekoop, R., George, S., Gunawardana, D., et al. (2015). The effect of adhesives and solvents on the capture and specimen quality of pest thrips on coloured traps. Crop Protection, 72, 108-111.

Dewar, A. M., \& Denholm, I. (2017). Chemical control. Aphids as Crop Pests Eds van Emden, H.F., \& Harrington, R. CABI, Wallingford, England, pp. 398-425.

Dewar, A. M., \& Foster, S. P. (2017). Overuse of pyrethroids may be implicated in the recent BYDV epidemics in cereals. Outlooks on Pest Management, 28(1), 7-12.

Doodson, J. K., \& Saunders, P. (1970). Some effects of barley yellow dwarf virus on spring and winter cereals in field trials. Annals of Applied Biology, 66(3), 361-374.

Fabre, F., Dedryver, C., Plantegenest, M., Hullé, M., \& Rivot, E. (2010). Hierarchical bayesian modelling of plant colonisation by winged aphids: Inferring dispersal processes by linking aerial and field count data. Ecological Modelling, 221(15), 1770-1778.

Fabre, F., Kervarrec, C., Mieuzet, L., Riault, G., Vialatte, A., \& Jacquot, E. (2003). Improvement of barley yellow dwarf virus-PAV detection in single aphids using a fluorescent real time RTPCR. Journal of Virological Methods, 110(1), 51-60.

Fabre, F., Pierre, J. S., Dedryver, C., \& Plantegenest, M. (2006). Barley yellow dwarf disease risk assessment based on bayesian modelling of aphid population dynamics. Ecological Modelling, 193(3-4), 457-466.

Gent, D. H., De Wolf, E., \& Pethybridge, S. J. (2011). Perceptions of risk, risk aversion, and barriers to adoption of decision support systems and integrated pest management: An introduction. Phytopathology, 101(6), 640-643.

Gent, D. H., Mahaffee, W. F., McRoberts, N., \& Pfender, W. F. (2013). The use and role of predictive systems in disease management. Annual Review of Phytopathology, 51, 267-289. 
Gray, S., \& Gildow, F. E. (2003). Luteovirus-aphid interactions. Annual Review of Phytopathology, 41(1), 539-566.

Handford, C. E., Elliott, C. T., \& Campbell, K. (2015). A review of the global pesticide legislation and the scale of challenge in reaching the global harmonization of food safety standards. Integrated Environmental Assessment and Management, 11(4), 525-536.

Harrington, R., Mann, J. A., Burgess, A. J., Tones, S. J., Rogers, R., Foster, G. N., et al. (1999). Development and validation of decision support methodology for control of barley yellow dwarf virus. HGCA Project Report,

Harrington, R., Hullé, M., \& Plantegenest, M. (2007). Monitoring and forecasting. Aphids as Crop Pests Eds van Emden, H.F., \& Harrington, R. CABI, Wallingford, England, pp. 515-531

Harrington, R., Verrier, P., Denholm, C., Hullé, M., Maurice, D., Bell, N., et al. (2004). EXAMINE (EXploitation of aphid monitoring in europe): An european thematic network for the study of global change impacts on aphids. Paper presented at the Aphids in a New Millennium. Proceedings of the Sixth International Symposium on Aphids, September 2001, Rennes, France, pp. 45-49.

Herbert, D. A., Stromberg, E. L., Chappell, G. F., \& Malone, S. M. (1999). Reduction of yield components by barley yellow dwarf infection in susceptible winter wheat and winter barley in virginia. Journal of Production Agriculture, 12(1), 105-109.

Holland, J., Bown, B., Clarke, J., \& McHugh, N. (2019). Patterns of cereal aphid infestation in autumn and implications for barley yellow dwarf virus control. IOBC-WPRS Bulletin, 143, 105-109.

Hull, R. (2009). Comparative plant virology Academic press.

Irwin, M. E., \& Thresh, J. M. (1990). Epidemiology of barley yellow dwarf: A study in ecological complexity. Annual Review of Phytopathology, 28(1), 393-424.

Jarošová, J., Beoni, E., \& Kundu, J. K. (2016). Barley yellow dwarf virus resistance in cereals: Approaches, strategies and prospects. Field Crops Research, 198, 200-214. 
Kendall, D. A., Brain, P., \& Chinn, N. E. (1992). A simulation model of the epidemiology of barley yellow dwarf virus in winter sown cereals and its application to forecasting. Journal of Applied Ecology, 414-426.

Knight, J. D. (1997). The role of decision support systems in integrated crop protection. Agriculture, Ecosystems \& Environment, 64(2), 157-163.

Kundu, J., Jarošová, J., Gadiou, S., \& Cervena, G. (2009). Discrimination of three BYDV species by one-step RT-PCR-RFLP and sequence-based methods in cereal plants from the Czech Republic. Cereal Research Communications, 37(4), 541-550.

Lankin-Vega, G., Worner, S. P., \& Teulon, D. (2008). An ensemble model for predicting rhopalosiphum padi abundance. Entomologia Experimentalis Et Applicata, 129(3), 308-315.

Lowles, A. J., Harrington, R., Tatchell, G. M., Tones, S. J., \& Barker, I. (1997). Aphid and virus dynamics to improve forecasts of barley yellow dwarf virus risk. HGCA Project Report,

Malmstrom, C. M., \& Shu, R. (2004). Multiplexed RT-PCR for streamlined detection and separation of barley and cereal yellow dwarf viruses. Journal of Virological Methods, 120(1), 69-78.

McGrath, P. F., \& Bale, J. S. (1989). Cereal aphids and the infectivity index for barley yellow dwarf virus (BYDV) in northern england. Annals of Applied Biology, 114(3), 429-442.

Met Office (2019): Met office Climate averages tables 1981 -2010 https://www.metoffice.gov.uk/public/weather/climate/gcn3y738h accessed June 2019

Miles, P. W. (1989). Specific responses and damage caused by aphidoidea. Aphids, their Biology, Natural Enemies and Control,100, 231-241.

Mori, Y., \& Notomi, T. (2009). Loop-mediated isothermal amplification (LAMP): A rapid, accurate, and cost-effective diagnostic method for infectious diseases. Journal of Infection and Chemotherapy, 15(2), 62-69. 
Ng, J. C., \& Perry, K. L. (2004). Transmission of plant viruses by aphid vectors. Molecular Plant Pathology, 5(5), 505-511.

Oakley, J. N., \& Walters, K. (1994). A field evaluation of different criteria for determining the need to treat winter wheat against the grain aphid sitobion avenae and the rose-grain aphid metopolophium dirhodum. Annals of Applied Biology, 124(2), 195-211.

Okazaki, S., Okuda, M., Komi, K., Yamasaki, S., Okuda, S., Sakurai, T., et al. (2011). The effect of virus titre on acquisition efficiency of tomato spotted wilt virus by frankliniella occidentalis and the effect of temperature on detectable period of the virus in dead bodies. Australasian Plant Pathology, 40(2), 120-125.

Pimentel, D., \& Lehman, H. (1993). The pesticide question: Environment, economics and ethics Springer Science \& Business Media.

Pisa, L. W., Amaral-Rogers, V., Belzunces, L. P., Bonmatin, J., Downs, C. A., Goulson, D., et al. (2015). Effects of neonicotinoids and fipronil on non-target invertebrates. Environmental Science and Pollution Research, 22(1), 68-102.

Plumb, R. T. (1974). Properties and isolates of barley yellow dwarf virus. Annals of Applied Biology, 77(1), 87-91.

Powell, S. J., \& Bale, J. S. (2006). Effect of long-term and rapid cold hardening on the cold torpor temperature of an aphid. Physiological Entomology, 31(4), 348-352.

R Core Team (2019). R: A language and environment for statistical computing. R Foundatio $\mathrm{n}$ for Statistical Computing, Vienna, Austria. URL https://www.R-project.org/

Ramsden, M. W., Kendall, S. L., Ellis, S. A., \& Berry, P. M. (2017). A review of economic thresholds for invertebrate pests in UK arable crops. Crop Protection, 96, 30-43.

Riedell, W. E., Kieckhefer, R. W., Langham, M. A., \& Hesler, L. S. (2003). Root and shoot responses to bird cherry-oat aphids and barley yellow dwarf virus in spring wheat. Crop Science, 43(4), 1380-1386.

Rochow, W. F. (1970). Barley yellow dwarf virus. CMI/AAB Descriptions of Plant Viruses, 32(4) 
Schröder, M. L., Glinwood, R., Ignell, R., \& Krüger, K. (2014). Visual cues and host-plant preference of the bird cherry-oat aphid, rhopalosiphum padi (hemiptera: Aphididae). African Entomology, 22(2), 428-437.

Shtienberg, D. (2013). Will decision-support systems be widely used for the management of plant diseases? Annual Review of Phytopathology, 51, 1-16.

Singh, R. P., Kurz, J., Boiteau, G., \& Moore, L. M. (1997). Potato leafroll virus detection by RTPCR in field-collected aphids. American Potato Journal, 74(5), 305-313.

Stern, V., Smith, R., Van den Bosch, R., \& Hagen, K. (1959). The integration of chemical and biological control of the spotted alfalfa aphid: The integrated control concept. Hilgardia, 29(2), 81-101.

Tatchell, G. M., Plumb, R. T., \& Carter, N. (1988a). Migration of alate morphs of the bird cherry aphid (rhopalosiphum padi) and implications for the epidemiology of barley yellow dwarf virus. Annals of Applied Biology, 112(1), 1-11.

van Emden, H. F., \& Harrington, R. (2017). Aphids as Crop Pests Eds van Emden, H.F., \& Harrington, R. CABI, Wallingford, England

Walls, J., Rajotte, E., \& Rosa, C. (2019). The past, present, and future of barley yellow dwarf management. Agriculture, 9(1), 23.

Watt, A. D. (1983). The influence of forecasting on cereal aphid control strategies. Crop Protection, 2(4), 417-429.

Woodcock, B. A., Bullock, J. M., McCracken, M., Chapman, R. E., Ball, S. L., Edwards, M. E., et al. (2016). Spill-over of pest control and pollination services into arable crops. Agriculture, Ecosystems \& Environment, 231, 15-23.

Zadoks, J. C., Chang, T. T., \& Konzak, C. F. (1974). A decimal code for the growth stages of cereals. Weed Research, 14(6), 415-421. 
388

389

390

391

392

393

394

395

396

397

398

399

400

401

402

403

404

405

Zhao, K., Liu, Y., \& Wang, X. (2010). Reverse transcription loop-mediated isothermal amplification of DNA for detection of barley yellow dwarf viruses in china. Journal of Virological Methods, 169(1), 211-214.

8

9

90

1

2

3

94

5

96

97


406 Figure 1. Variation over time exposed on trap in BYDV-PAV score of aphids according to florescence

407 detected above a baseline of 0 by q-PCR assay. Significance of deviation from the mean BYDV-PAV

408 score detected by the same method in aphids taken from the same infected colony but unexposed on 409 trap.

410

411

412

413

414

415

416

417

418

419

420

421

422

423

424

425

426

427

428 
429 Table 1. Air temperatures during trapping periods and average mean temperatures for Southern 430 England during October and November 1991-2010 (Met Office, 2019) 


\begin{tabular}{|c|c|c|c|c|c|}
\hline \multirow[b]{2}{*}{ Time series test } & 14 days to & $\operatorname{Max}^{\circ} \mathrm{C}$ & $\operatorname{Min}^{\circ} \mathrm{C}$ & Mean $\operatorname{Max}^{\circ} \mathrm{C}$ & Mean Min ${ }^{\circ} \mathrm{C}$ \\
\hline & 17th Dec & 12 & -3 & 9.3 & 4 \\
\hline \multicolumn{4}{|c|}{ October average England S 1991-2010 } & 14.4 & 7.2 \\
\hline \multicolumn{4}{|c|}{ November average England S 1991-2010 } & 10.3 & 4.1 \\
\hline
\end{tabular}

2

3

$4 \quad$ Table 


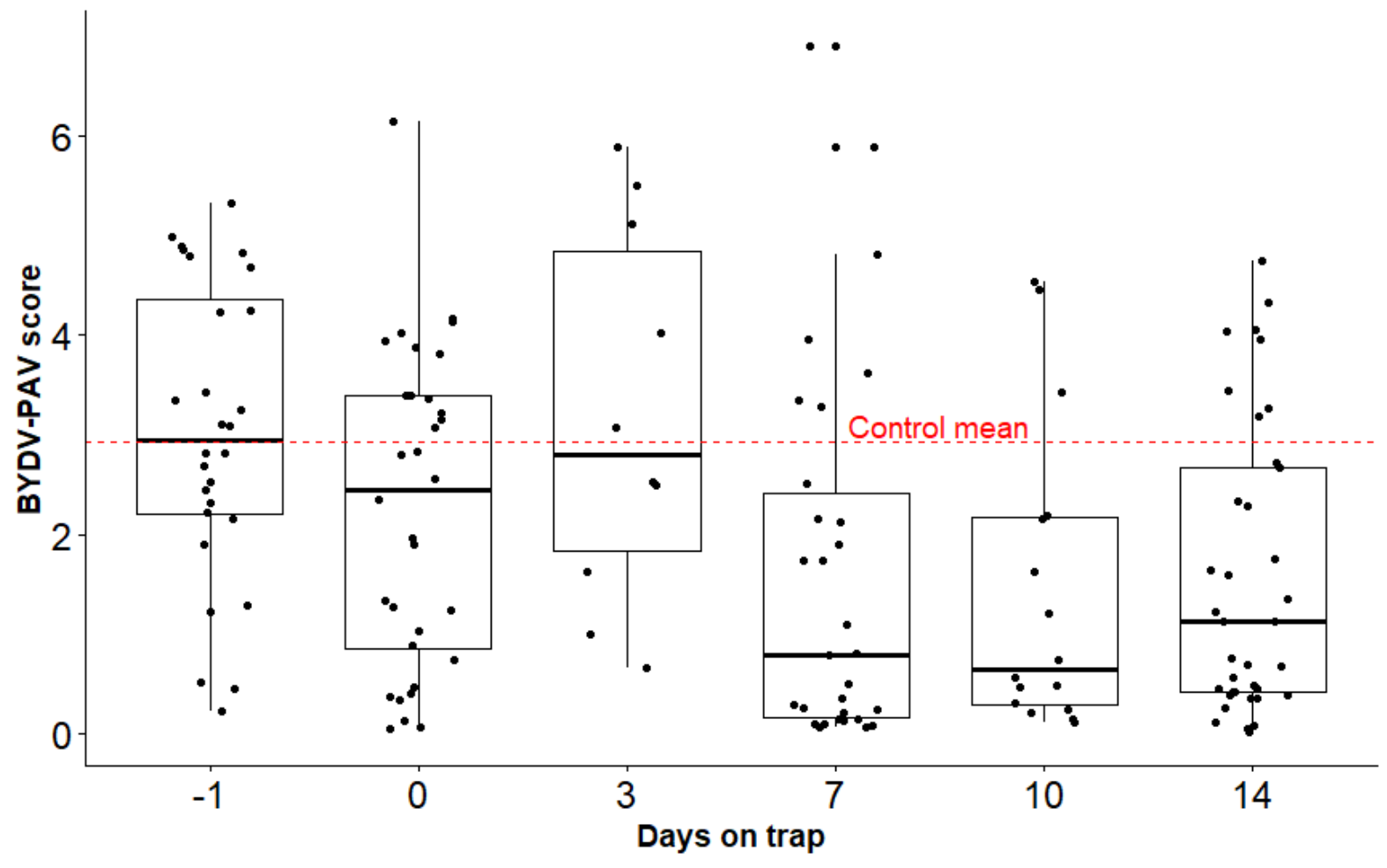

Figure 1. 